\title{
Revolutionising politics
}

Culture and conflict in England, 1620-6o

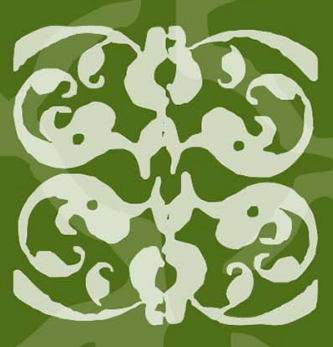

EDITED BY

PAUL D. HALLIDAY, ELEANOR HUBBARD AND SCOTT SOWERBY 


\section{Revolutionising politics}

\section{MANCHESTER 1824}

Manchester University Press 
Politics, culture and society in early modern Britain

General Editors

Professor Alastair Bellany

Dr Alexandra Gajda

Professor Peter Lake

Professor Anthony Milton

Professor Jason Peacey

This important series publishes monographs that take a fresh and challenging look at the interactions between politics, culture and society in Britain between 1500 and the mid-eighteenth century. It counteracts the fragmentation of current historiography through encouraging a variety of approaches which attempt to redefine the political, social and cultural worlds, and to explore their interconnection in a flexible and creative fashion. All the volumes in the series question and transcend traditional interdisciplinary boundaries, such as those between political history and literary studies, social history and divinity, urban history and anthropology. They thus contribute to a broader understanding of crucial developments in early modern Britain.

Recently published in the series

Chaplains in early modern England: Patronage, literature and religion HUGH ADLINGTON, TOM LOCKWOOD and GILLIAN WRIGHT (eds)

The Cooke sisters: Education, piety and patronage in early modern England GEMMA ALLEN Black Bartholomew's Day: Preaching, polemic and Restoration nonconformity DAVID J. APPLEBY

Insular Christianity: Alternative models of the Church in Britain and Ireland, c.1570-c.1700 ROBERT ARMSTRONG and TADHG Ó HANNRACHAIN (eds)

Reading and politics in early modern England: The mental world of a seventeenth-century Catholic gentleman GEOFF BAKER

'No historie so meete' JAN BROADWAY

Writing the history of parliament in Tudor and early Stuart England PAUL CAVILL and ALEXANDRA GAJDA (eds)

Republican learning: John Toland and the crisis of Christian culture, 1696-1722 JUSTIN CHAMPION

News and rumour in Jacobean England: Information, court politics and diplomacy, 1618-25 DAVID COAST

This England: Essays on the English nation and Commonwealth in the sixteenth century PATRICK COLLINSON

Gentry culture and the politics of religion: Cheshire on the eve of civil war RICHARD CUST and PETER LAKE

Sir Robert Filmer (1588-1653) and the patriotic monarch CESARE CUTTICA

Civil war London: Mobilising for parliament, 1641-5 JORDAN S. DOWNS

Doubtful and dangerous: The question of succession in late Elizabethan England SUSAN DORAN and PAULINA KEWES (eds)

\section{Brave community JOHN GURNEY} 'Black Tom' ANDREW HOPPER Reformation without end: Religion, politics and the past in post-revolutionary England ROBERT G. INGRAM

Freedom of speech, 1500-1850 ROBERT G. INGRAM, JASON PEACEY and ALEX W. BARBER (eds)

Connecting centre and locality: Political communication in early modern

England CHRIS R. KYLE and JASON PEACEY (eds)

Revolution remembered: Seditious memories after the British Civil Wars EDWARD JAMES LEGON

Royalists and Royalism during the Interregnum JASON MCELLIGOTT and DAVID L. SMITH

Laudian and Royalist polemic in Stuart England ANTHONY MILTON

The crisis of British Protestantism: Church power in the Puritan Revolution, 1638-44 HUNTER POWELL

Lollards in the English Reformation: History, radicalism, and John Foxe SUSAN ROYAL

The gentlewoman's remembrance: Patriarchy, piety, and singlehood in early Stuart England ISAAC STEPHENS

Exploring Russia in the Elizabethan Commonwealth: The Muscovy Company and Giles Fletcher, the elder (1546-1611) FELICITY JANE STOUT

Loyalty, memory and public opinion in England, 1658-1727 EDWARD VALLANCE

Church polity and politics in the British Atlantic world, c. 1635-66 ELLIOT VERNON and HUNTER POWELL (eds)

Full details of the series are available at www. manchesteruniversitypress.co.uk. 


\title{
Revolutionising politics
}

\section{Culture and conflict in England, 1620-60}

\author{
Edited by \\ Paul D. Halliday, Eleanor Hubbard \\ and Scott Sowerby
}


While copyright in the volume as a whole is vested in Manchester University Press, copyright in individual chapters belongs to their respective authors, and no chapter may be reproduced wholly or in part without the express permission in writing of both author and publisher.

Published by Manchester University Press

Altrincham Street, Manchester M1 7JA

www.manchesteruniversitypress.co.uk

British Library Cataloguing-in-Publication Data

A catalogue record for this book is available from the British Library

ISBN 9781526148155 hardback

First published 2021

The publisher has no responsibility for the persistence or accuracy of URLs for any external or third-party internet websites referred to in this book, and does not guarantee that any content on such websites is, or will remain, accurate or appropriate.

Typeset by

Servis Filmsetting Ltd, Stockport, Cheshire 